Article

\title{
Building Sustainable Societies through Purpose-Driven Universities: A Case Study from Ashoka University (India)
}

\author{
Anirban Chakraborty ${ }^{1,2, *(\mathbb{D})}$, Sumit $\operatorname{Kumar}^{1}$, L. S. Shashidhara ${ }^{1}$ and Anjali Taneja ${ }^{1}$ (D) \\ 1 Science Policy Initiatives, Ashoka University, Sonipat 131029, India; sumit.kumar1@ashoka.edu.in (S.K.); \\ 1s.shashidhara@ashoka.edu.in (L.S.S.); anjali.taneja@ashoka.edu.in (A.T.) \\ 2 International Centre for Higher Education Management, University of Bath, Bath BA2 7AY, UK \\ * Correspondence: anirban.chakraborty@ashoka.edu.in
}

check for

updates

Citation: Chakraborty, A.; Kumar, S. Shashidhara, L.S.; Taneja, A. Building Sustainable Societies through

Purpose-Driven Universities: A Case Study from Ashoka University

(India). Sustainability 2021, 13, 7423.

https://doi.org/10.3390/su13137423

Received: 24 May 2021

Accepted: 1 July 2021

Published: 2 July 2021

Publisher's Note: MDPI stays neutral with regard to jurisdictional claims in published maps and institutional affiliations.

Copyright: (c) 2021 by the authors. Licensee MDPI, Basel, Switzerland. This article is an open access article distributed under the terms and conditions of the Creative Commons Attribution (CC BY) license (https:// creativecommons.org/licenses/by/ $4.0 /)$.

\begin{abstract}
Sustainable Development (SD) is the universal essentiality of present times, and universities have a critical role in implementing this initiative through their functioning, policies and practices. To integrate SD goals, universities should have a global outlook that is still locally rooted in its strategies. In the last decade, various theories and recommendations have been proposed and adopted globally for integrating sustainability in higher education systems. In India, environmental education has been mandated at all formal levels in the education system. Still, there is a strong argument that it is not simply a matter of overhauling syllabi and curricula. Instead, universities should be incorporating SD goals into their research and their own operations. Our study aims to investigate the sustainability model of Ashoka University (India) that approaches its commitment through sustainability-focused courses, research, and operations. This study involves an in-depth literature review and uses an established framework to assess the condition of the university towards sustainability issues. Our case study employed observations, data collections, document reviews, and interactions with different stakeholders. The study concludes that the university is mostly in adherence with the framework at this stage. Critical areas of future development within the framework are proposed considering the global context. This research serves as an entry point for evaluating sustainability issues of the Indian higher education system, and hopes to motivate higher education communities to do further research to improve their sustainability performance and their role as agents of change.
\end{abstract}

Keywords: Indian higher education; sustainable development; sustainability model; sustainability approaches

\section{Introduction}

Traditionally, universities' role was primarily to educate young minds and offer them ample opportunities to use their potential for their self-growth and well-being. This perception has evolved gradually to include environmental management, public participation, community development and social responsibility in university teaching and research. In 1998, UNESCO declared that the responsibility of such institutions of higher learning is not only to educate the young population and provide them opportunities but also to educate them on how they can use their abilities and talent with the greatest sense of social responsibility [1]. According to Velazquez et al. [2], higher education institutes (HEIs) should promote minimisation of negative environmental, economic, societal, and health effects generated to fulfil its teaching, research, outreach, and partnership functions. Alshuwaikhat and Abubakar [3] define a sustainable campus as one that maintains a balance between economic prosperity, environmental conservation and social and economic justice. Thus, sustainability in educational institutions goes beyond environmental concerns and focuses on addressing social and economic challenges. There is a growing demand to include complex social issues such as racism, inequality, and poverty as part of universities' sustainability concepts [4]. 


\subsection{The Sustainability Debate}

The Stockholm Declaration of 1972 was the first declaration to make an indirect reference to sustainability in the higher education sector [5]. However, there has been an ongoing debate around the interpretation of the word 'sustainability' or 'sustainable development' [6]. The World Commission on Environment and Development defines sustainable development in its report titled 'Our Common Future', also known as the Brundtland Report [7]. The report explains Sustainable Development (SD) as "meeting the needs of the present generation without harming the future generations' capacity to meet their needs" [8]. There are three main pillars of sustainability-social, economic and environmental [9]. The Talloires Declaration of 1990 was the first statement from university administrators to commit to environmental sustainability in higher education [10]. After the Talloires Declaration there has been several national and international declarations and institutional policies related to environmental sustainability in HEIs [5]. The 17 Sustainable Development Goals (SDGs) adopted by the United Nations (General Assembly, 2015) represent a universal set of goals that are interconnected in a complex network of interactions. Their universality implies that none of the SDGs are prioritised, whereas their integrated multi-dimensional nature results in complex feedback between the SDG targets [11].

\subsection{Sustainability and HEIs}

Education is one of the critical aspects of the SDGs and HEIs play an important role in addressing the challenges of sustainable development through education and research [12-14]. Studies by Salvioni, Franzoni and Cassano [15] reinforce that universities constitute a fundamental vehicle to explore, test, develop and communicate essential conditions for SD [16]. Therefore, they need reforms in teaching and research [17]. In their study, Mohammadalizadehkorde and Weaver [18] highlighted three key reasons why universities should care about sustainability. First, the education and research institutions generate and disseminate knowledge on sustainability. Second, these institutions are semiautonomous communities and thus have the opportunities to implement evidence-based research practices to test the efficacy of those practices. Third, these institutions have the social responsibility to make the communities around them a better place. Watson et al. [19] revealed in their study the need for the teaching of sustainability concepts in a holistic way-i.e., covering environmental, economic and social dimensions-in the curriculum taught at the universities. Similarly, Colombo and Alves [20] emphasised promoting teacher training programs and interdisciplinary pedagogical methodologies to integrate sustainability as a concept in education. Teachers' awareness and training programs have also been emphasised in a survey undertaken by Uitto and Saloranta [21]. According to them, subject teachers' experience in sustainable education counts and must be taken into account in teacher training and education. Similarly, HEIs should also actively promote a contextual rethinking of curricular content to include the teaching of sustainability in all its dimensions [22]. In other words, the curriculum taught at HEIs must have a holistic vision. Researchers have also examined universities' critical role and responsibility and emphasised that teachings and research in such places must be focused on producing graduates as critical thinkers [23-25]. In their study, Nagy and Robb [26] reinforced the 'societal role of universities as institutions that equip individuals to become critical, analytical and adaptive is fundamentally linked with the ability to engage in questioning issues within society in a proactive way'. The term 'University Social Responsibility (USR)' was first coined by them and has been used to date as one of the significant parameters to evaluate a university's contribution towards development and community participation in society.

\subsection{Sustainability Issues in the Indian Higher Education System}

The Indian higher education sector's size and scale highlight its importance in addressing the nation's social, economic, and environmental sustainability. According to the All India Survey of Higher Education (2018-2019), nearly 37.4 million students are 
enrolled in the higher education sector. Currently, there are 993 universities, 39,931 colleges, and 10,725 stand-alone institutions [27]. Higher education has been acknowledged as a vital development driver for the country [28]. 'Environmental Education' (ED) has been a crucial strategy element in various policy documents by recognising the relationship between environment and development [29]. To make citizens more sensitive and responsible towards environmental issues, the country's highest court has mandated ED at all levels of education [29]. The University Grant Commission (UGC) of India also mandated an undergraduate environment course as the first step, providing an opportunity to introduce SD issues to higher education. The newly released National Education Policy (NEP 2020) also talks of the crucial responsibilities of HEIs in community engagement, support for the school system, and value-based education and ED [30]. However, the idea of sustainability in the Indian higher education system is nascent and under-researched, which primarily addresses environmental issues [31]. Unfortunately, Indian universities generally focus only on the curriculum, the intake number, faculty development, facilities, necessary infrastructure but not enough thought has been given to the campus sustainability [32]. We can see only a few universities and institutes that practising only certain aspects of sustainability. A study carried out at the Indian Institute of Science and Indian Institute of Technology (Kanpur) reported some sustainability aspects such as rainwater harvesting, waste and wastewater management, transportation, biodiversity enhancement and utilising renewable energy resources [31]. However, they have not taken any step to integrate these practices into their system. At TERI University, the researchers have used the initial environmental review (IER) and SWOT analysis to analyse the university's environmental concerns. Energy consumption, waste generation, transportation, energy efficiency, and water conservation were identified as the key parameters related to environmental sustainability [33]. Few universities are building the concept of SD through courses and programs in environmental studies and resource management [33]. Indian Institute of Technology (Madras) has a course on Technology and Sustainable Development. The Indian Institute of Management (Calcutta) Public Policy program offers courses on environment and development [29]. An analysis by Parvez and Avlokita [34] compared few rating systems and reported a comprehensive list of sustainability parameters to check the presence of these indicators in the Indian Institute of Technology Roorkee (IITR). The Indian Green Building Council (IGBC) has launched green campus rating systems to promote sustainability concepts [35]. Although government agencies have acknowledged environmental education as a crucial element in its development strategy, it is not widely reflected in India's social, economic or environmental realities. Additionally, the Indian higher education system has been criticised for these inadequacies [29]. Sustainability education and issues in most Indian universities are confined to specific courses and often isolated from research and are unlikely linked to campus operations [36]. Thus, HEIs in India possesses a tremendous opportunity to grow their sustainability initiatives. There is a need to focus more on research and studies to develop monitoring and assessment systems to determine how Indian HEIs are doing with sustainability and to pinpoint areas where they can improve [34,37].

\subsection{Purpose of This Study}

This study aims to investigate the sustainability model of an Indian university that approaches its commitment to sustainability through sustainability-focused courses, research initiatives, and operations. Given the complex nature of sustainability issues, SD education must pursue an integrative approach to modelling sustainability in the university's core functions and systems [36]. While it is challenging to implement changes in older Indian institutions, few new-aged institutions are managing things differently [38]. Ashoka University (AU), built on collective public philanthropy principles, has attempted to integrate education, research, and operations to address SD issues. The university, through official documents, has demonstrated its commitment to inclusion, diversity and emphasis on SD of 21st-century skills and leadership attributes. From the preliminary data and document 
analysis, we observed that currently, the university campus sits on 25 acres of land in Rajiv Gandhi Education City (RGEC) with a proposed vision to scale it up to 100 acres in 10 years. The university has various academic programmes (undergraduate to $\mathrm{PhD}$ ) and focused research areas in Humanities, Social Sciences, Economics, and Sciences. It is a fully residential campus with good facilities for extra-curricular activities. At the time of the research, the university had 132 faculty members, 546 staff members and 1998 students (56\% women). Its students on campus include international students from 27 countries and domestic students from over 29 states and 190 plus cities in India. For its unique governance model, premier global partnerships, distinguished faculty from around the world, innovative pedagogy and curriculum structure, we considered AU as a good case study model addressing university sustainability themes in a different way for the Indian higher education sector.

The idea is to critically review the AU's sustainability model and provide a case study to motivate higher education communities to make attempts towards making them platforms for testing various sustainability methods. This study will also help rethink and re-construct sustainability policies and practices and contribute in a better way to HEIs sustainable development at local, national and international levels.

\section{Sustainability Assessment Practices in HEIs}

Incorporating the concept of SD involving multiple stakeholders (teachers, staff and students) is a must for all HEIs [39]. As sustainability assessment gained the attention of several higher education policymakers and planners during past decades, multiple frameworks have been developed to assess university campuses' sustainability, with the tendency of witnessing more in coming years [40]. Most of the tools or frameworks developed have focused on the institutions in the western countries, with very few of them taking into account the context of the non-western countries. The Assessment Instrument for Sustainable Development in Higher Education (AISHE) was a qualitative tool developed by scholars in 2000 to do the sustainability assessment of two universities in the Netherlands. The tool has been further redeveloped, covering 30 indicators focusing on five dimensions for assessing the HEIs in western countries [41]. The Education for Sustainable Development and Global Citizenship framework was developed to assess the implementation of higher education in universities in the UK and Wales, and the Government of Wales supported the initiative. The framework focused on five key areas: commitment and leadership, teaching and learning, institutional management, partnerships, research, and monitoring [42]. Good Company's Sustainable Pathways toolkit was developed by a private company in the US; however, it lacked the inputs from the experts and actors related to the HEIs. The framework did not focus on research and stakeholder management to assess the university's sustainability initiatives [43]. The Higher Education Partnership for Sustainability is another framework developed by the 18 universities in the UK to monitor the implementation of sustainability in these universities. This framework mostly focused on organisational management change with less emphasis on the social indicators [43]. The Penn State Indicator Report (PSIR) was developed by the Penn State Green Density council to be applied to universities in Pennsylvania to communicate how these universities took the sustainability initiatives [44]. Applicability of this framework in other universities outside of the US is difficult. The Sustainability Assessment Questionnaire (SAQ) was developed by the secretariat of the Talloires Declaration to be used by all the universities signatory to the declaration. The framework used 35 indicators and focused on eight dimensions such as research, scholarship, operations, faculty, opportunities to the students, administration [45].

While the above examples highlight the models or frameworks developed by the scholars to assess the sustainability initiatives by HEIs in the western countries, there are examples of some frameworks for evaluating initiatives taken by the HEIs in the 'global south' or the non-western countries. To suit the assessment of sustainability in HEI in an Asian context, the researchers from the University of Hokkaido (Japan) developed the As- 
sessment System for Sustainable Campus (ASSC) framework in 2013. This framework used four categories; administrative, environmental, education, and regional society covering 170 criteria that were later used in other universities in Japan [46]. The Adaptive Model for Assessing Sustainability in Higher Education (AMAS) is a tool developed by scholars from Chile in 2015 consisting of four levels with an analytical hierarchy process applied to different weight criteria. The sustainability implementation in campus operation was given the highest weight [47]. The Alternative University Appraisal was developed by Promotion of Sustainability in Postgraduate Education and Research Network (ProsPER), an alliance of the academic institutions in Asia and Pacific regions. This framework consists of four categories; governance, education, research, and communication, applied to 28 universities in the Asia-pacific region [47]. The CITE AMB—Red de Ciencia, Tecnologia, Innovacion y Educación Ambienal em Iberoamerica framework developed by the Network of Science, Technology, Innovation and Environmental Education in Iberoamerica focused on four key areas: management, research, education and community in the university. This framework was developed to assess the university's sustainability initiatives in a non-western country such as Colombia [40]. The Unit Based Sustainability Assessment Tool (USAT) has been developed by the United Nations Environment Program (UNEP) using various frameworks such as SAQ and AISHE to assess the sustainability initiative led by the universities in Africa [48]. The University in Indonesia has developed the Green Metrics University Ranking to assess the environment-centric initiatives around energy, water, waste, and climate change. The framework has been used widely across the globe to assess similar university initiatives in higher education [49]. Even though most of these tools focus on the HEIs in non-western countries, they lack a holistic approach. Alshuwaikhat and Abubakar, researchers from Saudi Arabia, attempt to be more holistic and cover a wide range of dimensions to develop the integrated campus sustainability model. As a result, researchers have widely used this framework to assess the sustainability initiatives focusing on the HEIs in non-western countries [3]. Table 1 presents the comparison in terms of the key focus areas of popular sustainability assessment frameworks proposed for HEIs.

Table 1. Comparison of the key focus areas of popular sustainability assessment frameworks for HEIs.

\begin{tabular}{|c|c|}
\hline Framework & Key Focus Area \\
\hline $\begin{array}{l}\text { Assessment Instrument for Sustainable Development in } \\
\text { Higher Education (AISHE 1.0/AISHE 2.0) }[41,50]\end{array}$ & Operations, education, research, society, identity \\
\hline Penn State Indicator Report (PSIR) [44] & Campus, transport, decision support, research and community \\
\hline Sustainability Assessment Questionnaire (SAQ) [45] & $\begin{array}{c}\text { Curriculum, research and scholarship, operations, faculty and staff, } \\
\text { extension and services, student opportunities, administration, } \\
\text { mission and planning }\end{array}$ \\
\hline $\begin{array}{l}\text { Education for Sustainable Development and Global } \\
\text { Citizenship (ESDGC) [51] }\end{array}$ & $\begin{array}{c}\text { Commitment and leadership, Teaching and learning, Institutional } \\
\text { Management, Partnerships, Research and Monitoring }\end{array}$ \\
\hline Good Company's Sustainable Pathways toolkit (GC) [43] & Operations \\
\hline $\begin{array}{l}\text { Higher Education Partnership for Sustainability } \\
\text { (HEPS) [43] }\end{array}$ & Organisational management \\
\hline Integrated campus sustainability [3] & $\begin{array}{l}\text { Environmental management, public participation and service, } \\
\text { teaching, research }\end{array}$ \\
\hline Alternative University Appraisal (AUA) [47] & Governance, education, research and communication \\
\hline Unit Based Sustainability Assessment Tool (USAT) [48] & $\begin{array}{l}\text { Teaching, research and community services, operation and } \\
\text { management, student involvement, written policy and statement }\end{array}$ \\
\hline Green Metrics University (GMU) [49] & $\begin{array}{c}\text { Scenario and infrastructure, energy and climate change, waste, water, } \\
\text { transport, education and research }\end{array}$ \\
\hline
\end{tabular}


Table 1. Cont.

\begin{tabular}{cc}
\hline Framework & Key Focus Area \\
\hline $\begin{array}{c}\text { Adaptive Model for Assessing Sustainability in Higher } \\
\text { Education (AMAS) [47] }\end{array}$ & $\begin{array}{c}\text { Institutional commitment, leadership, } \\
\text { advanced sustainability }\end{array}$ \\
\hline $\begin{array}{c}\text { Graphical Assessment of Sustainability in University } \\
\text { (GASU) [52] }\end{array}$ & $\begin{array}{c}\text { Economic, environmental, social and educational } \\
\text { Management, education and research, } \\
\text { environment, local community }\end{array}$ \\
\hline $\begin{array}{c}\text { CITE AMB - Red de Ciencia, Tecnologia, Innovacion y } \\
\text { Educación Ambienal em Iberoamerica [40] }\end{array}$ & $\begin{array}{c}\text { Management, research, education, community } \\
\text { Sustainability Tracking Assessment and Rating System } \\
\text { (STARS, 2012) }\end{array}$ \\
\hline
\end{tabular}

Different popular tools for evaluating sustainability in higher education such as Sustainability Tracking Assessment and Rating System (STARS, 2012), Graphical Assessment of Sustainability in University-GASU [52], Assessment Instrument for Sustainability in Higher Education-AISHE [41], GIS-based model [53], Sustainable Campus Assessment System-SCAS [46], have different challenges in conducting campus sustainability assessments [43,54]. Further complexities arise in non-western countries due to regional variations. After studying and examining several campus sustainability assessment tools with a comprehensive review of extant literature, we selected the integrated campus sustainability framework proposed by Alshuwaikhat and Abubakar [3] to investigate AU's sustainability model. The main reason for adopting this framework was that it allowed all sustainability issues systematically and integrated [3]. Many researchers have applied it for the sustainability review of university campuses for the Middle-East and Asian countries [55]. Castro and Jabbour [56] have used this framework for evaluating sustainability in the Indian higher education context.

\section{Framework and Methodology}

The framework proposed by Alshuwaikhat and Abubakar [3] encompasses the environmental dimension of sustainability with social issues and organisational activities, preferring it more appropriate for our study $[57,58]$. It indicated that the sustainability of a university campus depends on three major axes of action: (i) Environment Management System (EMS) implementation; (ii) public participation and social responsibility; (iii) sustainability teaching and research (Figure 1).

An 'EMS' comprises a set of practices, procedures and processes of an organisation related to the environmental management system. The EMS assessment provides a balanced overview of identifying university's best practices regarding environmental aspects and impacts. The second vertical of the framework, 'Public participation and social responsibility' is related to participation, access and partnerships of the external medium with the university, the services offered to society and management of equality and diversity on the campus. Another vertical, 'Sustainability teaching and research', concerns the university's mission to promote sustainability by developing effective teaching, research and public services. It identifies and analyses courses, curriculum and subjects on sustainability offered to various audiences and research and development activities in the area [3].

We undertook a qualitative case study on AU's sustainability model. We designed the case study with 'particularistic', 'descriptive', and 'heuristic' features [59]. Particularistic, as this study focused on a specific situation of sustainability at a single institution of higher education in India. The study included analysis of several variables, and their interplay, over time (descriptive) and aimed to enhance and extend understanding of the sustainability model at an institution of higher education (heuristic) [60]. We examined a set of critical considerations for conducting the case study suggested by Corcoran et al. [61] 
for sustainability research in higher education. The study involved gathering information related to "ecological, social and economic dimensions of sustainability.

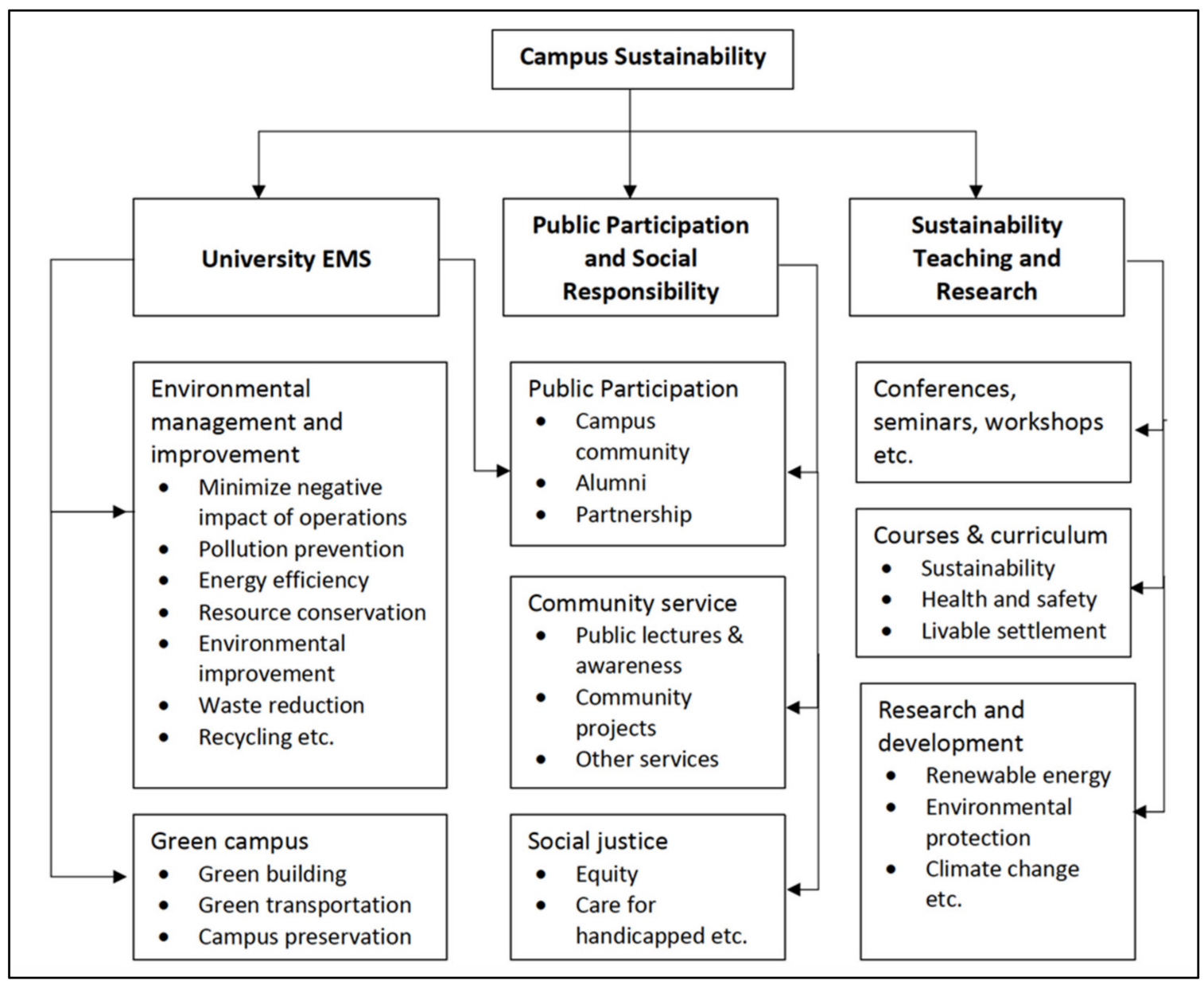

Figure 1. Framework for evaluating sustainability at universities. Source: Alshuwaikhat and Abubakar [3].

Following Yin's definition of a case study, we used multiple sources of evidence [62]. Our study included reviewing and analysing various policy documents and reports to collect information about AU's mission, vision, courses, curriculum, research, operations, student opportunities, outreach, and local community engagement. We made visits to classrooms, laboratories, libraries, dining areas, infirmary, construction sites, green zones, and power-houses of the campus to observe the reality. The team visited the admission, outreach, horticulture, maintenance and infrastructure offices. We also attended several events (conference, seminars, meetings) related to sustainability matters during the academic year (July 2019-June 2020). Documentary evidence of AU bulletins/calendars, speeches, mission statements, minutes of meetings, brochures reports helped understand different policies, strategies, and pro-grammes to support sustainability efforts. Most documents examined in this study are public documents obtainable on open sources, but we specifically solicited some documents for this study. During the study, we paid much attention to all the documents being used in this study in terms of the circumstances and contexts in which they were formulated.

Additionally, we administered semi-structured interviews consist of several key topics of discussion on sustainability issues (Table 2) with relevant university stakeholders (faculty, policymakers, and staff) to gather specific information on individual perspectives on AU's sustainability efforts [63,64]. We utilised the Alshuwaikhat and Abubakar [3] framework as the instrument for carrying out the interactions and discussions and used the thematic 
content analysis method for analysing the conversations $[65,66]$. The flexibility of this semistructured approach, particularly compared to structured interviews, is that the goal is not to reach definitive responses but rather to seek out how the interviewee understands what they have seen, heard, or experienced [64]. Interviews were carried out with 15 individuals. Five full-time faculty (including Deans), five researchers (from various disciplines), and five staff members (operations, outreach, admission, and consultant) participated during the study. Each respondent was interviewed at least once, for about an hour, or twice in three cases in order to obtain more information and clarify apparently unclear discussions. All the interviews were recorded and transcribed for thorough analysis and review afterwards. We marked all descriptions relevant to the topics of inquiry and identified distinct codes and categories (themes) using keywords or phrases copied from marked texts. We repeatedly went through the transcripts for identifying and revising distinct codes and categories for different groups. Transcripts of the interviews, findings and analysis were sent to all participants, and, in several cases, changes were made in accordance with the wishes of the participants. The relevant findings and analysis of semi-structured interviews were also compared with the data and information generated from documentary evidence. The method is appropriate since the relationship between universities and the sustainability theme is considered to be recent, and limited case studies and research articles are available in the Indian context. [56].

Table 2. Key topics of discussion on sustainability issues during semi-structured interviews with various stakeholders.

\begin{tabular}{|c|c|c|}
\hline Operations Teams & $\begin{array}{l}\text { Outreach, Student Affairs } \\
\text { and Admissions Teams }\end{array}$ & Deans, Faculty, Researchers \\
\hline $\begin{array}{l}\text { Protection of the environment; } \\
\text { limiting environmental } \\
\text { degradation; maintaining } \\
\text { indoor air quality standards } \\
\text { and practices; ensuring energy } \\
\text { conservation; waste reduction } \\
\text { and recycling; water } \\
\text { conservation and integrated } \\
\text { pest management practices; } \\
\text { sustainable landscaping and } \\
\text { maintaining natural } \\
\text { biodiversity; Transportation } \\
\text { and accommodation facilities. }\end{array}$ & $\begin{array}{l}\text { Activities/actions to ensure } \\
\text { active engagement; setting the } \\
\text { benchmark for students' } \\
\text { enrolment/admission; } \\
\text { involvement in sustainable } \\
\text { community work and service; } \\
\text { service-learning and/or } \\
\text { internship programs; student } \\
\text { groups across campus directly } \\
\text { involved in sustainability } \\
\text { initiatives. }\end{array}$ & $\begin{array}{l}\text { Sustainability focused } \\
\text { multidisciplinary teachings, } \\
\text { education, and research; } \\
\text { opportunities to enhance } \\
\text { teaching and research in } \\
\text { sustainability issues; } \\
\text { seminars and conferences for } \\
\text { promoting sustainability. }\end{array}$ \\
\hline
\end{tabular}

All interviews were administered virtually due to COVID-19 protocols. This might have potentially had an impact on the responses provided by them. The outcome of an interview very much depends on the local interactional contexts from within which both interviewees and interviewers work towards the construction of a particular story. Several studies have identified gaps between what people say they do and what actually happens inside their respective institutions. Despite their shared interest in sustainability, the participants in this study did not speak with one voice, although their level of agreement outweighed their level of disagreement on many issues. Nonetheless, a key outcome of this study was the surprising commonality of view between participants representing all three groups. Besides that, the current research lacks the students' perspective, who are the critical stakeholders for promoting sustainability. Social, economic, and environmental aspects are considered the three main pillars of this sustainability framework. While the Alshuwaikhat and Abubakar [3] framework captures the universities' social and environmental initiatives to achieve sustainability, it does not grasp the financial implications or indicators [55]. Additionally, other research methods, such as an extensive scale survey, was not considered be-cause the generalisability of findings is not the main concern of this study. 


\section{Results and Discussion}

The results focus on analysing the adherence between the framework developed by Alshuwaikhat and Abubakar and the efforts made by AU on addressing the issues related to sustainability. Table 3 is the summary of the initiatives taken by the university and its adherence to the Alshuwaikhat and Abubakar framework. The structure of the table has been borrowed from research papers published by other researchers who have used this framework for sustainability assessment $[55,56]$.

Table 3. Adherence of the initiatives taken by AU with the Alshuwaikhat and Abubakar framework (the structure is based on Castro and Jabbour [56]).

\begin{tabular}{|c|c|c|c|c|c|}
\hline Strategy & Initiatives & Activities & $\begin{array}{c}\text { Formally } \\
\text { Implemented }\end{array}$ & $\begin{array}{c}\text { Exist } \\
\text { Informally }\end{array}$ & No Action \\
\hline \multirow{10}{*}{ University EMS } & \multirow{7}{*}{$\begin{array}{c}\text { Environmental } \\
\text { management } \\
\text { and improvement }\end{array}$} & $\begin{array}{c}\text { Minimise negative impacts } \\
\text { of operations }\end{array}$ & & $\checkmark$ & \\
\hline & & Pollution prevention & & $\checkmark$ & \\
\hline & & Energy efficiency & & $\checkmark$ & \\
\hline & & Resource conservation & & $\checkmark$ & \\
\hline & & $\begin{array}{l}\text { Environmental } \\
\text { improvement }\end{array}$ & $\checkmark$ & & \\
\hline & & Waste reduction & & $\checkmark$ & \\
\hline & & Recycling & $\checkmark$ & & \\
\hline & \multirow{3}{*}{ Green campus } & Green buildings & & $\checkmark$ & \\
\hline & & Green transportation & & $\checkmark$ & \\
\hline & & Campus preservation & & $\checkmark$ & \\
\hline \multirow{8}{*}{$\begin{array}{l}\text { Public participation } \\
\text { and social } \\
\text { responsibility }\end{array}$} & \multirow{3}{*}{$\begin{array}{l}\text { Public } \\
\text { participation }\end{array}$} & Campus community & & $\checkmark$ & \\
\hline & & Alumni & $\checkmark$ & & \\
\hline & & Partnership & $\checkmark$ & & \\
\hline & \multirow{3}{*}{$\begin{array}{l}\text { Community } \\
\text { services }\end{array}$} & $\begin{array}{c}\text { Public lectures and } \\
\text { awareness }\end{array}$ & & $\checkmark$ & \\
\hline & & Community projects & $\checkmark$ & & \\
\hline & & Other services & & $\checkmark$ & \\
\hline & \multirow{2}{*}{ Social justice } & Equity & & $\checkmark$ & \\
\hline & & Care for handicap & $\checkmark$ & & \\
\hline \multirow{7}{*}{$\begin{array}{l}\text { Sustainability teaching } \\
\text { and research }\end{array}$} & $\begin{array}{l}\text { Conferences, } \\
\text { seminars, } \\
\text { workshops }\end{array}$ & $\begin{array}{l}\text { Conferences, seminars, } \\
\text { workshops }\end{array}$ & $\checkmark$ & & \\
\hline & \multirow{3}{*}{$\begin{array}{l}\text { Courses and } \\
\text { curriculum }\end{array}$} & Sustainability & $\checkmark$ & & \\
\hline & & Health and safety & $\checkmark$ & & \\
\hline & & Livable settlements & & $\checkmark$ & \\
\hline & \multirow{3}{*}{$\begin{array}{l}\text { Research and } \\
\text { development }\end{array}$} & Renewable energy & & $\checkmark$ & \\
\hline & & Environmental protection & & $\checkmark$ & \\
\hline & & Climate change & $\checkmark$ & & \\
\hline
\end{tabular}

The findings indicate that $\mathrm{AU}$ has made efforts to follow sustainability drives in and around the campus. This not only extends/stretches into its teachings and research but also across the natural environment, energy consumption, water management, food waste reduction and recycling, resource conservation, healthcare, sanitation, transportation, public participation and social justice. 


\subsection{University Environmental Management System (EMS)}

EMS is a standard approach to assess the direct and indirect impact of the operations and activities of the HEIs [67]. EMS can be considered as a series of policy evaluation, planning, formulating, and employing environmental strategies [68]. Thus, EMS establishment is the key for the HEIs to integrate their environmental sustainability in their operations and activities. However, before establishing the EMS, it is important to assess the environmental impact of the university's operations and activities. The impact of the operations and activities can be categorised into both direct and indirect. While the direct impact refers to the effects generated because of the consumption of power, water and generation of waste (organic and inorganic), the indirect impact relates to impacts caused because of the transportation of students, staff through (road, rail and air) and construction activities $[3,67]$.

\section{Environmental Management and Green Campus}

$\mathrm{AU}$ is located in the state of Haryana and is part of the National Capital Region (NCR), one of the country's fastest urbanising regions. Rapid urbanisation has affected the climate as well as the air quality of the region [69]. National Highway 1 (NH 1) runs next to the university, built-in 25 acres of land with a future plan to expand to 100 acres. The heavy vehicles' regular movement on the $\mathrm{NH}$ is a constant source of noise and air pollution in the region. To address the problem of noise and air pollution, the university has planted trees along its boundary, which creates a natural barrier to guard against the dust and noise caused due to movement of heavy vehicles.

Electricity is essential for the lightning of several academic and non-academic buildings, including the library, common areas, pathways, among several others. The university currently has a high dependence on the electricity supplied from external sources such as the power plants operated by the state and private companies. At present, a small amount of electricity used in the operations is generated internally using renewable energy sources such as solar. In order to reduce its carbon footprint, the university has taken several measures. Focusing on energy-efficient buildings is one of the major initiatives led by the university. Under this initiative, the university plans to become self-reliant in energy production and consumption. The plan is to use solar energy by installing solar panels on the buildings' rooftops to meet the majority of their energy requirement. However, the government's policy of buying back the extra electricity produced through the decentralised grids has not been implemented yet, thereby leading to a delay in expanding the current solar production capacity of the university. However, this should not deter the university from enhancing its current capacity to produce solar energy to meet the campus's energy needs. Various initiatives led by the university have helped reduce the energy load, but electricity consumption has gone up over the years. Even though the efforts to reduce energy consumption are voluntary, the university has conducted two audits in the past to keep track of its efforts to reduce its carbon footprint. While complex interventions such as installing solar panels are critical in reducing the carbon footprint reduction in electricity usage, it is equally important to focus on soft interventions to reduce energy consumption, thereby achieving the carbon footprint target. Nudging human behaviour through digital intervention has been a strategy to decrease energy consumption [70].

AU should plan to use this strategy by installing digital meters in the hostels and further use the data generated from these digital meters to nudge students' behaviour to reduce energy consumption. In an effort to encourage students, faculty and staff members of different departments to shape up their idea on sustainability, Yale University launched a pilot in 2009. As a part of the pilot, each department was suggested to create a document that reflected how the school's discipline is connected to the university's sustainability priorities. Although the pilot was not but very successful, it laid the foundation stone to promote the sustainability culture within the university departments. During the period 2013-2016, Yale University announced the Yale Sustainability Strategic Plan where-in each department prepared their respective plans to support the institutional level goals. The 
plans made by the different departments included various initiatives such as the reduction in the emission of greenhouse gases, recycling of waste, among several others [71]. AU can also undertake similar initiatives to promote sustainability by keeping the university's key stakeholders in the planning and implementation.

$\mathrm{AU}$ is located in the northern part of India, and in this region, water is a scarce resource [72], and thus, it is crucial to reduce the water footprint [73]. The geographical location where the university is located has witnessed a sharp decline in the groundwater table in the past several years [74]. Therefore, recycling water to reduce the carbon footprint is very important from the sustainability perspective. The university consumes water in day-to-day activities, such as supply for the university-managed food courts, cafeterias, residential areas, cleaning, construction and gardening at the university premises, among several other activities. As part of an initiative to recycle, the wastewater coming out of the kitchen is passed through various grease traps, further fed into the water treatment plant. The wastewater coming from the toilet is connected to the sewage treatment plant of 100 kilo litres per day (KLD) and 300 KLD for recycling. This recycled water is then further used for irrigation of the lawns and green areas on the campus.

Food is an important source of generation of both organic and inorganic waste inside the university campus. The organic and non-organic wastes are segregated in the campus at the beginning of their sources. Nearly $70 \mathrm{~kg}$ of kitchen waste generated every day is handed over to the local piggery, while $30 \mathrm{~kg}$ of waste from the food plates is incinerated and converted into manure, which is used to meet the internal requirement in the university. Concerning the generation of hazardous waste, science laboratories such as biology labs and chemistry labs are the primary sources. The authority takes proper measures to properly collect and hand over the waste to authorised vendors only.

Construction activities are a source of different kinds of pollution and generation of waste. Construction can have both short-term and long-term impacts on environmental sustainability. Noise generated by the construction activity affects the well-being of the people in and around the university campus. Thus, to mitigate its short-term impact, construction activities are avoided during the nighttime. Efforts have also been made to reduce the impact of oil spills in the soil because of the new campus's construction. Jali (shaded structure) has been used for shading, LED bulbs have been used to reduce the consumption of electricity, and sensors have been used in the urinal to minimise the wastage of water. Moreover, to reduce the energy requirement for cooling the buildings, the peripheral walls are made up of blocks instead of bricks.

Besides focusing on environmental sustainability as part of the construction activity, the university has also focused on ensuring inclusive education for students irrespective of their disabilities. Taking cognisance of the students with certain disabilities, the university has focused on constructing the ramps in all building entrances, braille signage and accessible toilet facility. The university authorities felt that there was less focus on sustainability during the construction of the existing campus; however, in the construction of the new campus, a sustainability expert has been hired to have a greater emphasis on sustainability.

Transportation poses a considerable challenge to sustainable development [75]. Many students and faculty members use vehicles operating on fossil fuels such as petrol or diesel for commuting to the campus. The university has made efforts to encourage bicycles and battery-operated cars for mobility and transportation of people and goods within the campus.

Although the efforts made by the university to conserve the scarce resource such as water, recycle the waste and reduce the impact caused because of the operations is in the right direction it not sufficient. This is also because of the lack of a standard mechanism in India to track these efforts. Alshuwaikhat and Abubakar have argued the need for an environmental audit to assess the universities' performance to achieve environmental sustainability. Several universities worldwide have received external certifications such as the ISO 14001 or Eco-Management and Audit Scheme (EMAS) to prescribe the sustainability initiatives taken by the university in the US and Europe. AU has conducted energy audits 
but has not received any external certification that would certify if the current practices of the university complaint with the environmental management. AU may become signatories to various conventions or declarations such as the Higher Education Sustainability Initiative (HESI) created in 2012 in the run-up to the United Nations conference on sustainable development $($ Rio +20$)$. Initiatives such as these will reaffirm the university's commitment to sustainable development. Lack of funds is a major challenge for supporting projects focused on promoting sustainability to achieve long-term and short-term benefits [76]. To address this gap, the University of Melbourne used the university governance structure to fund the carbon reduction projects to trade off the short-term benefits with programs of longer-term benefits [77]. AU could also initiate similar initiatives to promote campus sustainability.

\subsection{Public Participation and Social Responsibility}

AU is one of the few liberal arts HEI in India [78]. The university website and admission brochures highlight that the university's vision is to help students become well-rounded individuals who can think critically about issues from multiple perspectives, communicate effectively, and become leaders with a commitment to public service. Official reports of operation, admission and outreach offices confirm that AU engages with, involves and inspires people on its campus, communities, and around the world to understand social inclusion and how it can foster inclusive and effective solutions. This has been reinforced during multiple discussions and interactions with various faculty and staff members of AU.

\subsubsection{Public Participation and Community Services}

AU's annual reports (2016-2020) suggest that the university aims to deepen the involvement and engagement with the local communities through opportunities to meet, share knowledge, collaborate, and inspire mutual benefit. Several research projects and programmes are being carried out within the state of Haryana by AU's faculty and students to engage the local communities. These initiatives address local issues such as streamlining the implementation of the state government's policies in the field of education, women's safety, health and sanitation, higher education and e-governance [79]; Stubble burning-a major cause of air pollution in North India [80]; optimising testing for COVID-19 [81]; conducting studies on archaeological sites [82].

Concurrently, the university also carries out social engagement and public participation through various centres such as the Centre for Social Impact and Philanthropy (CSIP) - focused on enabling strategic and robust philanthropy for greater social impact [83], Centre for Social and Behaviour Change (CSBC) — designs, advances and enables evidence led communication interventions for low income and marginalised Indian communities, and Centre for Studies in Gender and Sexuality (CSGS) - to study the nuances of these issues concerning both gender and sexuality in India. These centres are trying to entrench SD principles, including social justice, equity, democracy and religious tolerance, significantly relevant to Indian societies. The local engagement is also fostered through various partnership programmes, the flagship being the Chief Minister's Good Governance Associates (CMGGA) Programme-a strategic collaboration with the Government of Haryana. CMGGA is directed towards improving governance in the state and driving a mass impact on the ground [84].

Public engagement covers the many ways HEI can connect, share and involve the public with its work locally, nationally and internationally [85]. AU has a dedicated media and outreach office, which sets out its vision to carry out high-quality engagement. According to one of the Deans, "We aim to create supportive environments for faculty, staff and students to engage, understand and work with diverse audiences and to evidence the impact". The office of Student Life organises multiple on-campus cultural and intellectual activities all around the year. Our study identified nearly 18 languages are spoken on the campus. Over 25 student-run clubs and societies function in different fields such as sports, fashion, 
entrepreneurship, animation, quizzing. They prove to be an opportunity to contribute and enrich the campus experience and create an interactive space for artists and performers to express themselves. The university has increased its public outreach through domestic and international partnerships. For example, the university has been conducting various exchange programmes through its Global Education and Strategic Programs office with its partner institutions globally [86]. It also offers an Advanced Summer Internship Programme (ASIP) with social impact groups, research organisations.

\subsubsection{Social Justice}

Public participation and social engagement cannot be successfully carried out by a university unless actively supported by scholarships and grants [85]. Our findings confirm that AU runs scholarship programmes to ensure quality education accessible to deserving students, irrespective of their socio-economic backgrounds, ethnicity, gender, gender identity or disability. It offers merit scholarships to deserving students and needbased aid, including fee waivers, ranging from $25 \%$ on tuition to $100 \%$ on all expenses. The financial reports suggested that AU has provided need-based financial aid of USD 34.2 million to over 3000 students in the last ten years. In 2020-21, nearly USD 8.4 million in aid has already been granted by the university and over $51 \%$ of undergraduate students at Ashoka are studying on financial assistance. The university also has tie-ups with financial institutions that provide education loans at affordable rates without any collateral. It actively reaches out to low-income schools and Non-Government Organisations in remote areas of the country to admit students.

The university offers care for students with learning disabilities or psychological support through special centres such as the Office of Learning Support (OLS) or the Ashoka Centre for Well Being (ACWB). OLS acts as a central resource centre on specificneeds-related information and services for the university and promotes collaborative approaches to implement inclusion policies. The annual reports of the OSL suggest that it has supported students with visual/hearing impairment, ASD, and cerebral palsy over the years. On the other hand, the ACWB serves as a safe space to offer free and confidential counselling support to the entire Ashoka community for the healthy development of mind, body and soul. The team of counsellors, professionals and volunteers of ACWB offers specialised services to help students build emotional resources and develop better-coping strategies. These are unique initiatives in the Indian context, and AU should popularise and encourage this as essential and mandatory support [87]. It is important to conduct a third-party assessment suggesting how and to what extent have these initiatives and activities contributed to fulfilling the universities' commitment to sustainability.

\subsection{Sustainability Teaching and Research}

AU's vision document, offering liberal education, focuses on providing holistic and comprehensive teachings and sustainability research. The future of liberal education depends on how best one creates and explores new forms of education that can enhance social justice, public service, and environmental sustainability while also developing students to lead a new era of growth and change [88].

\subsubsection{Courses and Curriculum}

O'Byrne et al. [89] stated that shared foundations between programs are essential for developing mature sustainability courses that are understood by academics, employers, and civil society and are effective in training the next generation. Various discussions with faculty revealed that AU's course structure fosters connection with the public and society at the undergraduate level itself. According to one of the faculty, "At Ashoka, the consistent exchange of knowledge through training, workshops, conferences, public lectures on diverse topics enrich the thought process and network of young minds, thereby building their social circle". Since its inception, AU has been advocating an interdisciplinary mode of education and teaching. 
For example, its undergraduate programme is multidisciplinary to expose students to different perspectives in and out of the classroom [90].

Foundation courses such as Critical Thinking, Quantitative Reasoning and Environmental Studies are being designed to help cultivate students' analytical ability. Simultaneously, the co-curricular courses in Performing Arts, Visual Arts, and Language strengthen students' extra-curricular skills, helping them cope with real-world challenges. Subjectspecific lessons taught at Ashoka are mostly cross-disciplinary. In the Environmental Studies department, some of the courses such as 'Agriculture, Food and Sustainability'; 'Environment and Social Exclusion'; 'Exploring Life in the Neighbourhood Lab'; 'Environmental Economics'; 'Cities, Ecology and Equity' are closely linked to the concept of sustainability. The curriculum designed for one of the courses on Indian Civilisations (foundation course) introduces students to Indian history, emphasising the diversity of Indian culture and tradition. Sustainability-oriented teachings are also ingrained in the curriculum offered by the departments of Economics and Sciences. Within the course on 'Economy, Politics and Society', students are introduced to the various ways in which economic thoughts have shaped geography, history and institutions and how basic concepts such as work and labour define individuals and society. A foundation course, Principles of Science, deals with the evolution of scientific thoughts and landmark discoveries, helping students understand the essence of scientific temper characterised by unbiased observations and multiple validations and falsification methods.

Besides the standard degree courses, the university also runs programmes such as Young Scholars Programme (YSP), Young India Fellowship (YIF), postgraduate diploma in Advanced Studies and Research and Ashoka-X (specially crafted programs and course offerings through the online medium to a wider audience). Such programmes help AU to offer many higher education packages and learnings on sustainability in all its dimensions.

However, other exciting initiatives started by various universities worldwide can be replicated by AU, considering the local context. One such initiative is the Eco-Reps program, which was started at Tufts University [91]. The initiative's main objective is to increase the students' overall awareness about environmental issues and promote green campus projects. The Eco-reps have to attend a weekly class organised around the topics related to recycling, water conservation, climate change and other sustainability-related issues. The students who successfully complete the course received a monthly stipend.

\subsubsection{Interdisciplinary Research}

During the discussions, many faculty have highlighted that AU's interdisciplinary nature of research pushes the boundaries and bridges disciplines to open possibilities for exploration. The mission document describes that the university aims to pioneer trans-disciplinary research and teaching that create lasting societal impacts. The university currently has four board areas of disciplines: arts and humanities, social sciences, economics and basic sciences. Research at the university is driven mainly by faculty/researchers from all departments/centres with various interests. Some of their thrust areas are bound traditionally within the same disciplines, while others are compatible with new and evolving specialisation areas. In addition to discipline-focused research activities, the university has encouraged interdisciplinary research projects through its popular research centres such as the CSBC, CSIP, CSGS, Centre for Writing and Communication (CWC), and Centre for Entrepreneurship, and Centre for Economic Data and Analysis (CEDA). Our study revealed that students, researchers and faculty are engaged in over 80 ongoing research projects (2019-2020) addressing sustainability issues in fields ranging from history, anthropology, sociology, economics to environment and basic sciences. Few departments and centres at AU also conduct evidence-based research and knowledge sharing through its particular policy cell such as the Science Policy Initiative, which promotes data-driven research, policy work and advocacy on India's science, technology and innovation landscape [92]. Researchers at AU have made a significant contribution to the study of Covid-19 [93]. India's first large-scale agent-based simulation model for Covid-19 has been developed at AU [94]. 
From working on the mathematical model for optimising testing for COVID-19 in India to collaborating with different institutes, understanding the pandemic and lockdown's effects on the social, economic sector as well as on wide-range aspects of life-Ashoka's faculty's efforts in this field have been highlighted in scholarly works $[81,95,96]$.

The university is making efforts with its experienced faculty to develop new initiatives and research centres to expand its horizon and scope of research and higher education in sustainability fields. As an immediate next step, AU is all set to start its new Centre for Climate Change and Sustainability (3Cs) - to strengthen collaborations in this field, enhance education, research and awareness on climate change, and build a strong climate action community. Some of the proposed initiatives under the 3Cs include online international climate change conferences, lecture series, building a networking and outreach community, generating proposals for legal remedies, and facilitating summer projects for students.

\subsubsection{Conferences, Seminars, Training, Workshops}

Literature reinforces the aspect that meetings and conferences are an important medium for HEIs to promote various issues of sustainability through knowledge-sharing, experiences, projects, initiatives and methods [97]. AU's academic departments and centres actively promote SD concepts by organising conferences, seminars, specialised lectures, symposia series, and workshops for the students, faculty, and staff. Specialised centres (OLS and ACWB) organise programs for the welfare and well-being of the students, faculty and staff at AU. For example, the OLS's remedial support instructional program helps students with disabilities to achieve expected competencies in core academic skills such as literacy and numeracy. Similarly, ACWB's Gatekeeper Program is explicitly designed to identify and address mental constraints such as anxiety, depression and connect those in need of counselling help with the centre. Such initiatives help in improving the well-being of the Ashoka community. Since the nationwide lockdown announced in India as a result of the COVID-19 pandemic, AU has introduced a series of online programs such as the 'Scientifically Speaking' lecture series and 'Beyond the Classroom' seminar series to enable a sustained and continuous process of learning and development. Our study identified 136 events (conferences, seminars, workshops) organised by the university during the academic year (2019-2020) addressing sustainability issues in various fields.

This study aims to analyse AU's key sustainability approaches through sustainabilityfocused courses, research, and vital operational strategies adopted for the environmentfriendly campus, well-being, diversity and inclusion, and outreach. We have reviewed new research areas promoted at AU to address the issues related to sustainability. Analysis has been done on the new course curriculum and pedagogy designed to ensure sustainable knowledge creation, communication, research and teaching. Table 3 systematically shows the adherence between the framework and the condition at AU. In general, the university has developed all of the sustainability strategies suggested in the framework. Ten strategies are formally implemented; twelve strategies are informally implemented. In summary, we may indicate that $\mathrm{AU}$ at the time this research was performed had mostly adherence levels concerning the framework's strategies.

Sustainable development is crucial to the future of the entire planet. Ensuring social cohesion, economic prosperity, and protection of the environment are the main pillars of the SDGs framework. HEIs play a significant role in the education, research, innovation, culture, and capacity building, essential in achieving the SDGs. This study's findings build on the extant literature on sustainability of HEIs as it provides information and data on sustainability policy and approaches of an Indian university. Re-imagining the societal role and responsibility of HEIs, and associate operational changes has deep and rich epistemic roots. Investigating the transformational roles of HEIs by breaking disciplinary silos and bridging theory and practice through purpose-driven organisations is crucial to make societies more sustainable. The assessment of the sustainability model of AU can serve as guidelines to develop sustainability campus models for other HEIs in India, such as large universities and technical institutes (IITs). Scaling up of this model is important in a 
fast-changing world for the better preparedness of any nation and for its uncertain future. Being the largest producer of skilled human resources globally, India's adoption of sustainability education in HEIs benefits the entire world. The study can inform the decisions of policymakers and administrators at HEIs to develop and implement policies to create a learning environment to imbue sustainability perspectives into various stakeholders.

\section{Conclusions}

This study has critically reviewed what AU has accomplished in promoting sustainability. The university has shown its commitment to SD issues through the delivery of focused courses, research and operations. Since its inception, the university has implemented strategies and taken initiatives directed towards ensuring affordability and access, well-being and welfare, diversity and inclusion, as well as outreach and engagement of its community, i.e., students, faculty, and staff. The pedagogy, courses, curriculum, activities taught/undertaken at the university have been designed to promote sustainability in exchanging knowledge, communication, research and teaching. Our noteworthy finding is that AU manages its functions differently and provides guidance to the community towards social upliftment and environmental sustainability by explicitly linking research, educational, and internal operational activities. This study has also revealed that although AU contributes to reaching the sustainability goals, it should pay considerable attention to adopt global best sustainability practices. More formal approaches and external audit processes are needed in specific areas for future development. Moreover, the sustainable development of Indian universities should look beyond the narrowed definition of environmental aspects and broaden their roles to exert social and economic perspectives.

This study delineates the current debate governing the promotion of sustainability in an HEI in a globalised world. Further, it has made an attempt to critically analyse the sustainability approaches of an Indian university, i.e., AU, through a framework, suggested for non-western countries. This work serves as an entry point for evaluating sustainability issues of the Indian higher education system. The framework proposed by Alshuwaikhat and Abubakar is a valuable instrument in assessing the campus sustainability of Indian universities. However, given the diversity (regional, social, economic, cultural and geographical) in Indian university campuses, it is not easy to implement or follow a homogeneous system or model. Further research on policy approaches, data analyses, and review of specific case studies would provide practical insights with a specific understanding of this complex topic. After all, a university is a place where learning is continuous, and adaptation to new norms and practices is the best way to ensure sustainable development in higher education.

Author Contributions: A.C. and L.S.S. conceived of the presented idea; A.C. developed the methodology and framework; A.C., A.T., and S.K. performed the study, drafted the manuscript; S.K. designed the figure; L.S.S. encouraged and A.C. supervised the study and analysis. All authors discussed and contributed to the final manuscript. All authors have read and agreed to the published version of the manuscript.

Funding: This research received no external funding.

Institutional Review Board Statement: Not applicable for this study.

Informed Consent Statement: Informed consent was obtained from all subjects involved in the study.

Acknowledgments: We are grateful to Mahesh Rangarajan, Shivani Krishna, and Deboshruti Raychaudhury for their insights. Thanks are also due to Sachin Sharma, Bhaskar Mishra and Vikas Garg for their feedbacks.

Conflicts of Interest: The authors declared no potential conflict of interest with respect to the research, authorship, and/or publication of this article. 


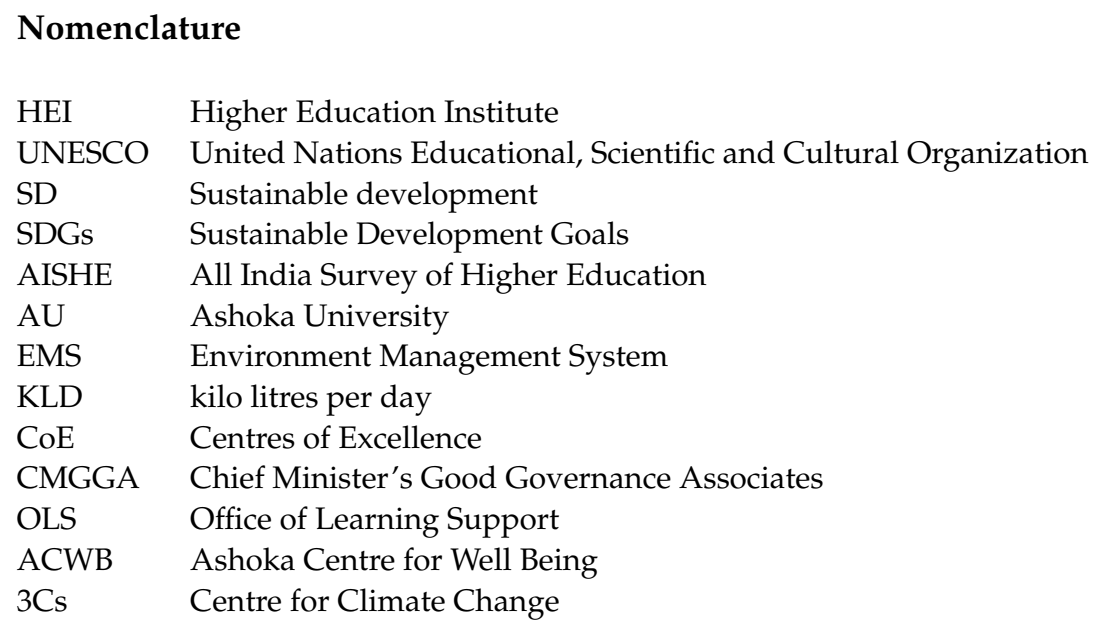

\section{References}

1. UNESCO. World Declaration on Higher Education for the Twenty-First Century, for Vision and Action; UNESCO: Paris, France, 1998.

2. Velazquez, L.; Munguia, N.; Platt, A.; Taddei, J. Sustainable university: What can be the matter? J. Clean. Prod. 2006, 14, 810-819. [CrossRef]

3. Alshuwaikhat, H.M.; Abubakar, I.R. An integrated approach to achieving campus sustainability: Assessment of the current campus environmental management practices. J. Clean. Prod. 2008, 16, 1777-1785. [CrossRef]

4. Steiner, G.; Posch, A. Higher education for sustainability by means of transdisciplinary case studies: An innovative approach for solving complex, real-world problems. J. Clean. Prod. 2006, 14, 877-890. [CrossRef]

5. Wright, T.S. Definitions and frameworks for environmental sustainability in higher education. Int. J. Sustain. High. Educ. 2002, 3 , 203-220. [CrossRef]

6. Yuan, X.; Zuo, J.; Huisingh, D. Green Universities in China-What matters? J. Clean. Prod. 2013, 61, 36-45. [CrossRef]

7. United Nations. Report of the World Commission on Environment and Development: Our Common Future; UN: Geneva, Switzerland, 1987.

8. Salvia, A.L.; Filho, W.L.; Brandli, L.L.; Griebeler, J.S. Assessing research trends related to Sustainable Development Goals: Local and global issues. J. Clean. Prod. 2019, 208, 841-849. [CrossRef]

9. Purvis, B.; Mao, Y.; Robinson, D. Three pillars of sustainability: In search of conceptual origins. Sustain. Sci. 2019, 14, 681-695. [CrossRef]

10. Ramirez, M. Commitments of University Leaders to the Talloires Declaration: Are They Evidenced in Industrial Design Teaching and Learning? In Integrative Approaches to Sustainable Development at University Level: Making the Links; World Sustainability Series; Springer: Cham, Switzerland, 2015; pp. 225-244.

11. Swain, R.B.; Ranganathan, S. Modeling interlinkages between sustainable development goals using network analysis. World Dev. 2021, 138, 105136. [CrossRef]

12. Mochizuki, Y.; Fadeeva, Z. Competences for sustainable development and sustainability. Int. J. Sustain. High. Educ. 2010, 11, 391-403. [CrossRef]

13. Boström, M.; Andersson, E.; Berg, M.; Gustafsson, K.; Gustavsson, E.; Hysing, E.; Lidskog, R.; Löfmarck, E.; Ojala, M.; Olsson, J.; et al. Conditions for Transformative Learning for Sustainable Development: A Theoretical Review and Approach. Sustainability 2018, 10, 4479. [CrossRef]

14. Eizaguirre, A.; García-Feijoo, M.; Laka, J.P. Defining Sustainability Core Competencies in Business and Management Studies Based on Multinational Stakeholders' Perceptions. Sustainability 2019, 11, 2303. [CrossRef]

15. Salvioni, D.M.; Franzoni, S.; Cassano, R. Sustainability in the Higher Education System: An Opportunity to Improve Quality and Image. Sustainability 2017, 9, 914. [CrossRef]

16. Filho, W.L. (Ed.) Sustainable Development at Universities: New Horizons; Peter Lang D: Bern, Switzerland, 2013.

17. Brito, R.M.; Rodríguez, C.; Aparicio, J.L. Sustainability in Teaching: An Evaluation of University Teachers and Students. Sustainability 2018, 10, 439. [CrossRef]

18. Mohammadalizadehkorde, M.; Weaver, R. Universities as Models of Sustainable Energy-Consuming Communities? Review of Selected Literature. Sustainability 2018, 10, 3250. [CrossRef]

19. Watson, M.K.; Lozano, R.; Noyes, C.; Rodgers, M. Assessing curricula contribution to sustainability more holistically: Experiences from the integration of curricula assessment and students' perceptions at the Georgia Institute of Technology. J. Clean. Prod. 2013, 61, 106-116. [CrossRef]

20. Colombo, C.R.; Alves, A.C. Sustainability in engineering programs in a Portuguese Public University. Production 2017, 27. [CrossRef]

21. Uitto, A.; Saloranta, S. Subject Teachers as Educators for Sustainability: A Survey Study. Educ. Sci. 2017, 7, 8. [CrossRef] 
22. Bone, E.; Agombar, J. First Year Attitudes Towards, and Skills in, Sustainable Development; The Higher Education Academy: York, UK, 2011.

23. Bleiklie, I. Institutional Conditions and the Responsibilities of Universities. 2004. Available online: https://core.ac.uk/download/ pdf/30895731.pdf (accessed on 22 January 2021).

24. Gunasekara, C. Reframing the Role of Universities in the Development of Regional Innovation Systems. J. Technol. Transf. 2005, 31, 101-113. [CrossRef]

25. Atakan, M.G.S.; Eker, T. Corporate Identity of a Socially Responsible University-A Case from the Turkish Higher Education Sector. J. Bus. Ethics 2007, 76, 55-68. [CrossRef]

26. Nagy, J.; Robb, A. Can universities be good corporate citizens? Crit. Perspect. Account. 2008, 19, 1414-1430. [CrossRef]

27. AISHE. All India Survey on Higher Education 2018-19. 2019. Available online: http://aishe.nic.in/aishe/viewDocument.action? documentId=262 (accessed on 22 January 2021).

28. Das, S. The Higher Education in India and the Challenge of Globalisation. Soc. Sci. 2007, 35, 47-67. Available online: https: / / www.jstor.org/stable/27644205 (accessed on 22 January 2021).

29. Chhokar, K.B. Higher education and curriculum innovation for sustainable development in India. Int. J. Sustain. High. Educ. 2010, 11, 141-152. [CrossRef]

30. Kumar, K.; Prakash, A.; Singh, K. How National Education Policy 2020 can be a lodestar to transform future generation in India. J. Public Aff. 2020. [CrossRef]

31. Bantanur, S.; Mukherjee, M.; Shankar, R. Emerging dimensions of sustainability in institutes of higher education in India. Int. J. Sustain. Built Environ. 2015, 4, 323-329. [CrossRef]

32. Bantanur, S.; Mukherjee, M.; Shankar, R. Sustainability perceptions in a technological institution of higher education in India. Curr. Sci. 2015, 109, 2198-2203. [CrossRef]

33. Jain, S.; Aggarwal, P.; Sharma, N.; Sharma, P. Fostering sustainability through education, research and practice: A case study of TERI University. J. Clean. Prod. 2013, 61, 20-24. [CrossRef]

34. Parvez, N.; Avlokita, A. Review of Campus Sustainability Rating Systems for Indian Campuses. In Proceedings of the 52nd International Conference of the Architectural Science Association, Melbourne, Australia, 28 November-1 December 2018; pp. 503-510.

35. IGBC. IGBC Green New Buildings Rating System, Hyderabad (India). 2014. Available online: https://igbc.in/igbc/html_pdfs/ abridged/IGBC\%20Green\%20New\%20Buildings\%20Rating\%20System\%20(Version\%203.0).pdf (accessed on 22 January 2021).

36. Mcmillin, J.; Dyball, R. Developing a Whole-of-University Approach to Educating for Sustainability. J. Educ. Sustain. Dev. 2009, 3, 55-64. [CrossRef]

37. Priyadarshini, P.; Abhilash, P.C. From piecemeal to holistic: Introducing sustainability science in Indian Universities to attain UN-Sustainable Development Goals. J. Clean. Prod. 2020, 247, 119133. [CrossRef]

38. Chakraborty, A. Foreign partnership in Indian higher education: Significance, challenges and concerns. Glob. Soc. Educ. 2020 1-14. [CrossRef]

39. Filho, W.L.; Brandli, L. (Eds.) Engaging Stakeholders in Education for Sustainable Development at University Level; Springer International Publishing: Cham, Switzerland, 2016.

40. Caeiro, S.S.; Sandoval-Hamón, L.A.; Martins, R.; Aldaz, C.E.B. Sustainability Assessment and Benchmarking in Higher Education Institutions-A Critical Reflection. Sustainability 2020, 12, 543. [CrossRef]

41. Roorda, N.; Martens, P. Assessment and Certification of Higher Education for Sustainable Development. Sustain. J. Rec. 2008, 1, 41-56. [CrossRef]

42. Kapitulčinová, D.; AtKisson, A.; Perdue, J.; Will, M. Towards integrated sustainability in higher education-Mapping the use of the Accelerator toolset in all dimensions of university practice. J. Clean. Prod. 2018, 172, 4367-4382. [CrossRef]

43. Yarime, M.; Tanaka, Y. The Issues and Methodologies in Sustainability Assessment Tools for Higher Education Institutions: A Review of Recent Trends and Future Challenges. J. Educ. Sustain. Dev. 2012, 6, 63-77. [CrossRef]

44. P. S. University. Penn State Indicators Report 2000: Steps toward a Sustainable University; P. S. University: University Park, PA, USA, 2000; Volume 108.

45. ULSF. Sustainability Assessment Questionnaire. 2001. Available online: http://ulsf.org/sustainability-assessment-questionnaire/ (accessed on 22 January 2021).

46. Hokkaido University Sustainable Campus Management Office. Assessment System for Sustainable Campus; Hokkaido University Sustainable Campus Management Office: Sapporo, Japan, 2013.

47. Gómez, F.U.; Sáez-Navarrete, C.; Lioi, S.R.; Marzuca, V.I. Adaptable model for assessing sustainability in higher education. J. Clean. Prod. 2015, 107, 475-485. [CrossRef]

48. Rhodes University. Unit-Based Sustainability Assessment Tool. 2014. Available online: https://www.ru.ac.za/elrc/ publicationsandresources/unit-basedsustainabilityassessmenttoolusattool/ (accessed on 22 January 2021).

49. Lauder, A.; Sari, R.F.; Suwartha, N.; Tjahjono, G. Critical review of a global campus sustainability ranking: GreenMetric. J. Clean. Prod. 2015, 108, 852-863. [CrossRef]

50. Roorda, N. AISHE 1.0. Assessment Instrument for Sustainability in Higher Education. English Text; Dutch Foundation for Sustainability in Higher Education: Amsterdam, The Netherlands, 2001. 
51. Glover, A.; Peters, C.; Haslett, S.K. Education for sustainable development and global citizenship. Int. J. Sustain. High. Educ. 2011, 12, 125-144. [CrossRef]

52. Lozano, R. A tool for a Graphical Assessment of Sustainability in Universities (GASU). J. Clean. Prod. 2006, 14, 963-972. [CrossRef]

53. Alshuwaikhat, H.M.; Abubakar, I.R.; Aina, Y.A.; Adenle, Y.A.; Umair, M. The Development of a GIS-Based Model for Campus Environmental Sustainability Assessment. Sustainability 2017, 9, 439. [CrossRef]

54. Shriberg, M. Institutional assessment tools for sustainability in higher education. Int. J. Sustain. High. Educ. 2002, 3, 254-270. [CrossRef]

55. Ulkhaq, M.M.; Prayogo, P.I.; Firmansyah, M.; Agustina, D. Assessing Campus Sustainability: A Report from Diponegoro University, Indonesia. Int. J. Inf. Educ. Technol. 2016, 6, 616-621. [CrossRef]

56. De Castro, R.; Jabbour, C.J.C. Evaluating sustainability of an Indian university. J. Clean. Prod. 2013, 61, 54-58. [CrossRef]

57. Setó-Pamies, D.; Papaoikonomou, E. A Multi-level Perspective for the Integration of Ethics, Corporate Social Responsibility and Sustainability (ECSRS) in Management Education. J. Bus. Ethic. 2015, 136, 523-538. [CrossRef]

58. Wang, Y.; Shi, H.; Sun, M.; Huisingh, D.; Hansson, L.; Wang, R. Moving towards an ecologically sound society? Starting from green universities and environmental higher education. J. Clean. Prod. 2013, 61, 1-5. [CrossRef]

59. Merriam, S.B. Qualitative Research and Case Study Applications in Education. Revised and Expanded from "Case Study Research in Education"; Jossey-Bass Publishers: San Francisco, CA, USA, 1998.

60. Ii, E.E.A.; Giddens, E.; Glassmeyer, D.; Gruss, A.; Hedden, M.K.; Slinger-Friedman, V.; Weand, M. Sustainability Education and Organizational Change: A Critical Case Study of Barriers and Change Drivers at a Higher Education Institution. Sustainability 2019, 11, 501. [CrossRef]

61. Corcoran, P.B.; Wals, A.E. Case studies, make-your-case studies, and case stories: A critique of case-study methodology in sustainability in higher education. Environ. Educ. Res. 2004, 10, 7-21. [CrossRef]

62. Yin, R.K. The abridged version of case study research: Design and method. In Handbook of Applied Social Research Methods; Sage Publications, Inc: Thousand Oaks, CA, USA, 1998; pp. 229-259.

63. Adams, W.C. Conducting Semi-Structured Interviews. In Handbook of Practical Program Evaluation; Wiley: Hoboken, NJ, USA, 2015; pp. 492-505.

64. Gill, P.; Stewart, K.; Treasure, E.T.; Chadwick, B.L. Methods of data collection in qualitative research: Interviews and focus groups. Br. Dent. J. 2008, 204, 291-295. [CrossRef] [PubMed]

65. Anderson, R. Thematic Content Analysis (TCA): Descriptive Presentation of Qualitative Data. 2007. Available online: http: //rosemarieanderson.com/wp-content/uploads/2014/08/ThematicContentAnalysis.pdf (accessed on 22 January 2021).

66. Burnard, P. A method of analysing interview transcripts in qualitative research. Nurse Educ. Today 1991, 11, 461-466. [CrossRef]

67. Ercilla, P.E. Environmental sustainability assessment of an academic institution in Calamba City. Norm. Light. 2017, 11, 235-263.

68. Clarke, A.; Kouri, R. Choosing an appropriate university or college environmental management system. J. Clean. Prod. 2009, 17, 971-984. [CrossRef]

69. Sati, A.P.; Mohan, M. The impact of urbanization during half a century on surface meteorology based on WRF model simulations over National Capital Region, India. Theor. Appl. Clim. 2017, 134, 309-323. [CrossRef]

70. Kroll, T.; Paukstadt, U.; Kreidermann, K.; Mirbabaie, M. Nudging People to Save Energy in Smart Homes with Social Norms and Self-Commitment. In Proceedings of the European Conference on Information Systems (ECIS), Stockholm and Uppsala, Sweden, 8-14 June 2019.

71. ISCN and GULF. Best Practice in Campus Sustainability. 2014. Available online: https://international-sustainable-campusnetwork.org/iscn-sustainable-campus-best-practices / (accessed on 22 January 2021).

72. Joseph, N.; Ryu, D.; Malano, H.M.; George, B.; Sudheer, K. Investigation into sustainable water use in India using combined large-scale earth system-based modelling and census-based statistical data. J. Hydrol. 2020, 587, 124930. [CrossRef]

73. Feeley, T.J.; Skone, T.J.; Stiegel, G.J.; McNemar, A.; Nemeth, M.; Schimmoller, B.; Murphy, J.T.; Manfredo, L. Water: A critical resource in the thermoelectric power industry. Energy 2008, 33, 1-11. [CrossRef]

74. Singh, J.P.G.; Singh, D.M.; Nain, M. Variability Analysis of Groundwater Depth: A Case Study of Sonipat District in Haryana. Int J. Agric. Sci. 2019, 11, 8738-8743.

75. Mosaberpanah, M.A.; Khales, S.D. The Role of Transportation in Sustainable Development. In Proceedings of the ICSDEC 2012: Developing the Frontier of Sustainable Design, Engineering, and Construction, Fort Worth, TX, USA, 7-9 November 2012; American Society of Civil Engineers (ASCE): Reston, VA, USA, 2012; pp. 441-448.

76. Velazquez, L.; Munguia, N.; Sanchez, M. Deterring sustainability in higher education institutions. Int. J. Sustain. High. Educ. 2005, 6, 383-391. [CrossRef]

77. Silvestre, B. Sustainable supply chain management: Current debate and future directions. Gestão Prod. 2016, 23, 235-249. [CrossRef]

78. Sud, P.M.; Narayan, P.P.; Agarwal, M. Entrepreneurship and the Liberal Arts: The Making of Ashoka University. Indian Inst. Manag. Ahmedabad 2019, 1-24. [CrossRef]

79. CMGGA. An Outlook for Change. 2018. Available online: http://www.cmgga.in/uploads/AnOutlookforChangeWITHCOVERfinal20-5-2019.pdf (accessed on 22 January 2021).

80. Agarwala, M.; Chandel, A. Temporal role of crop residue burning (CRB) in Delhi's air pollution. Environ. Res. Lett. 2020, 15, 114020. [CrossRef] 
81. Cherian, P.; Krishna, S.; Menon, G.I. Optimising testing for COVID-19 in India. medRxiv 2021. [CrossRef]

82. Lahiri, N. Archaeology and the Public Purpose; Oxford University Press (OUP): Oxford, UK, 2021.

83. Hartnell, C. Philanthropy in India; Philanthropy for Social Justice and Peace: Brussels, Belgium; Ashoka University: New Delhi, India, 2017.

84. CMGGA. Durbeen: A Young Perspective of Working with the Government. 2019. Available online: http://cmgga.in/uploads / CMGGA-YearBook-2018-19.pdf (accessed on 22 January 2021).

85. Vargiu, A. Indicators for the Evaluation of Public Engagement of Higher Education Institutions. J. Knowl. Econ. 2014, 5, 562-584. [CrossRef]

86. Penprase, B. New Liberal Arts and Sciences Institutions in India and Singapore: The Role of STEM Education. In Experiences in Liberal Arts and Science Education from America, Europe, and Asia; Springer Science and Business Media LLC: Berlin, Germany, 2016; pp. 61-73.

87. Gaur, K.; Ram, U. Mental health problems among youth in India and its correlates. Int. J. Hum. Rights Heal. 2016, 9, 95-108. [CrossRef]

88. Cornwell, G.; Stoddard, E. The Future of Liberal Education and the Hegemony of Market Values: Privilege, Practicality, and Citizenship. Lib. Educ. 2001 (Summer), 87, 3. Available online: https://www.aacu.org/publications-research/periodicals/ future-liberal-education-and-hegemony-market-values-privilege (accessed on 22 January 2021).

89. O'Byrne, D.; Dripps, W.; Nicholas, K.A. Teaching and learning sustainability: An assessment of the curriculum content and structure of sustainability degree programs in higher education. Sustain. Sci. 2014, 10, 43-59. [CrossRef]

90. Singh, K. Building a Center for Writing and Communication: Inclusion, Diversity and Writing in the Indian Context. In Diversity and Inclusion in Global Higher Education; Springer Science and Business Media LLC: Berlin, Germany, 2020; pp. $209-227$.

91. Erickson, C.; Skoglund, C. Eco-Reps Programs: Conducting Peer Outreach in Residence Halls. Sustain. J. Rec. 2008, 1, 57-72. [CrossRef]

92. Taneja, A.; Shashidhara, L.S.; Bhattacharya, A. Rare diseases in India: Time for cure-driven policy initiatives and action. Curr. Sci. 2020, 118. [CrossRef]

93. Mandal, S.; Roychowdhury, T.; Bhattacharya, A. Pattern of genomic variation in SARS-CoV-2 (COVID-19) suggests restricted nonrandom changes: Analysis using Shewhart control charts. J. Biosci. 2021, 46, 1-7. [CrossRef]

94. Menon, G.I. Models for COVID-19 and beyond in India: A Grand Challenge. Indian Acad. Sci. Conf. Ser. 2020, 3. [CrossRef]

95. Deshpande, A. The Covid-19 Pandemic and Lockdown: First Effects on Gender Gaps in Employment and Domestic Work in India. 2020. Available online: https://ideas.repec.org/p/ash/wpaper/30.html (accessed on 22 January 2021).

96. Gohain, S. Pandemic of Inequality and the State: A Response to Maitrayee Chaudhuri's 'COVID-19 and Structural Inequalities: Some Reflections on the Practice of Sociology'. Sociol. Bull. 2021, 70, 264-268. [CrossRef]

97. Berchin, I.I.; Sima, M.; de Lima, M.A.; Biesel, S.; dos Santos, L.P.; Ferreira, R.V.; Guerra, J.B.S.O.D.A.; Ceci, F. The importance of international conferences on sustainable development as higher education institutions' strategies to promote sustainability: A case study in Brazil. J. Clean. Prod. 2018, 171, 756-772. [CrossRef] 